Received 2 December 2020 Accepted 4 December 2020

Link to DOI:

10.25220/WNJ.V05.i1.0012

Journal Website: www.worldnutrijournal.org

\title{
Fluid consumption, hydration status, and its associated factors: A cross sectional study among medical students in Palembang, Indonesia
}

Dwi Lisa Nur'aini, ${ }^{1}$ Ardesy Melizah Kurniati, ${ }^{2}$ Moretta Damayanti, ${ }^{3}$ Syarif Husin, ${ }^{2}$ Joko Marwoto, ${ }^{4}$

1. Faculty of Medicine, Universitas Sriwijaya, Palembang, Indonesia

2. Department of Nutrition, Faculty of Medicine, Universitas Sriwijaya, Palembang, Indonesia

3. Nutrition and Metabolic Disease Division, Child Health Department, Faculty of Medicine, Universitas Sriwijaya-Moehammad Hoesin General Hospital, Palembang, Indonesia

4. Department of Biology Medicine, Faculty of Medicine, Universitas Sriwijaya, Palembang, Indonesia

\begin{tabular}{l} 
Abstract \\
Background: Adequate fluid consumption and hydration status of students have become a special \\
concern because being dehydrated by just 1-2\% may impair cognitive performance. The objectives \\
of this study were to assess the daily fluid consumption and to analyze the correlation of fluid \\
consumption and other associated factors with hydration status of medical students in Universitas \\
Sriwijaya. \\
Methods: A total of 93 medical students in Universitas Sriwijaya were recruited to complete a 7- \\
day cross-sectional study. Subjects were asked to complete a self-administered 7-day-24-hours fluid \\
record and provide first morning urine sample on the last day. Gender information was collected. \\
Physical activity was evaluated by self-administered long version of IPAQ. Body mass index was \\
calculated using body weight and body height measurement. Urine specific gravity was determined \\
by urinometer. The 7-day-24-hours fluid record and 1-day-24-hours urine specific gravity were \\
calculated and analyzed. \\
Results: Majority of the subjects were well hydrated, while $10.8 \%$ were slightly dehydrated, $6.5 \%$ \\
were moderately dehydrated and $9.7 \%$ were severely dehydrated. The average of daily fluid \\
consumption was 1789.28 ( $989.3-2930)$ mL. Coefficient correlation of fluid consumption from \\
beverages with urine specific gravity was -0.651 (p=0.00) by Pearson correlation test. The hydration \\
status showed no association with gender, physical activity and body mass index. \\
Conclusions: Most subjects in this study were well hydrated. A strong association was found \\
between fluid consumption and hydration status. It was feasible to use daily fluid consumption \\
from beverages to predict hydration status. \\
Keywords fluid consumption, urine specific gravity, hydration status \\
\hline
\end{tabular}

\section{Introduction}

Dehydration is a condition when the body loses fluids due to inadequate consumption or as a result

Corresponding author:

Ardesy Melizah Kurniati

Faculty of Medicine, Universitas Sriwijaya, Palembang, Indonesia

Email:ardesy.gizi@fk.unsri.ac.id of excessive loss. ${ }^{1,2}$ Dehydration can cause a variety of signs and symptoms differentiated based on the percentage of water loss. Mild dehydration (1-5\%) can cause excessive thirst, loss of taste, uncomfortable feeling, dry mouth, decreased urine output, work and concentration difficulty, warm skin on palpation, drowsiness, vomitus and unstable emotions. Moderate dehydration (5-10\%) can cause an increase in body temperature, increased heart rate and breathing, dizziness, shortness of breath, 
sluggish speech, and blue lips. Severe dehydration $(\geq 10 \%)$ can cause seizures, hallucinations, swollen tongue, poor circulation, kidney failure, and decreased blood volume and pressure. ${ }^{3,4}$

Several factors are related to hydration status, such as fluid consumption, gender, physical activity, and body mass index. Adequate fluid consumption is necessary to maintain body fluids in a balanced condition. Study by Zhang, 2017 found that there was a significant difference between the consumption of fluids that came from drinks and hydration status. ${ }^{5}$ Men has higher fluid turnover rate than women, hence more dehydration can be observed in men than women. ${ }^{6}$ Dieny and Putriana, 2015 conducted a study which showed that there was a significant relationship between hydration status before training and hydration status after training in teenage soccer athletes. ${ }^{7}$ Body mass index is related to hydration status in which the water content in the fat cells of obese people is lower than the water content in muscle cells, therefore obese students are more dehydrated than non-obese students in the study by Buanasita, $2015 .^{8}$

The hydration status of students needs serious attention and concern because dehydration, even at mild levels, is associated with impairments in cognitive performance. ${ }^{9}$ The objectives of this study were to identify gender, age, physical activity, body mass index, fluid consumption, fluid consumption patterns, and hydration status, to analyze factors associated with hydration status, and to analyze the correlation of fluid consumption with urine specific gravity in students of Medical Education Program, Faculty of Medicine, Universitas Sriwijaya, Palembang.

\section{Methods}

This was an observational analytic study with a cross-sectional approach conducted on students of class 2014 until class 2017 of Medical Education who met the inclusion and exclusion criteria. Medical students investigated in this study were all registered as active students in Medical Education Program, Faculty of Medicine, Sriwijaya University. Exclusion was carried out on medical students who were in any of the following circumstances: (1) having fever that was examined directly by the researcher with a thermometer, (2) taking anti-cholinergic drugs (lomotil, phenothiazine, and others), diuretics (furosemide, amiloride, and others), tricyclic antidepressant drugs (amitriptyline, prozac, and others), analgesics (ibuprofen, acetaminophen, and others) confirmed by subject characteristic form, (3) defecating soft or liquid stool at least three times in 24 hours confirmed by selection form, (4) having forceful oral eviction of gastrointestinal contents confirmed by selection form, (5) suffering from kidney problems and diabetes confirmed by a doctor's examination that the subject had previously known, (6) having menstruation that affected urine samples, (7) providing insufficient amount of urine (less than 50 $\mathrm{mL}$ ), (8) were under 18 years old and did not get parental consent or guardian, and (9) during the study period were not around the Faculty of Medicine, Sriwijaya University.

Selection of subjects is carried out by distributing selection forms and measuring body temperature. Body temperature measurements are carried out by direct examination using a digital thermometer. Physical activity data were collected using the IPAQ physical activity questionnaire form. This physical activity questionnaire was conducted to assess the physical activity performed during the previous seven days with self-administered format. The results of the physical activity questionnaire were then classified into low physical activity, moderate physical activity, and high physical activity. Body mass index data were collected by measuring body weight and height and then recorded on a physical examination form. Fluid consumption was taken with a 1x24 hour fluid record and the fluid consumption pattern was obtained from a $7 \times 24$ hour fluid record. Retrieval of hydration status data was taken using a urinometer to obtain the specific gravity value of urine. The urine used is the first urine expelled immediately after waking up before breakfast and before doing activities and has been stored in the bladder for no less than four hours.

Descriptive data analysis was used to identify gender, age, physical activity, body mass index, fluid consumption, fluid consumption patterns, hydration status in students. Chi-square test was used to analyze the relationship of hydration status with gender, physical activity and fluid consumption. Fisher's exact test was performed to analyze the relationship of hydration status with body mass index because it did not meet the Chi- 
square test requirements. Pearson Correlation was used to analyze the correlation of fluid consumption with urine specific gravity test.

\section{Results}

Of 120 subjects, 27 subjects were not enrolled as they dropped out or met the exclusion criteria. A total of 93 subjects completed $100 \%$ of the study. Data were analyzed. Most of the subjects $(66.7 \%)$ were female and were $\geq 19$ years $(64.5 \%)$. Table 1 shows general characteristics of subjects.

Specific characteristics of the subjects can be seen in Table 2. The majority of the subjects had low level of physical activity $(52.7 \%)$, had nonobese body mass index (82.8\%), and had not adequate fluid consumption $(53.8 \%)$.

Table 3 reports the fluid consumption pattern of subjects in this study. The average fluid types majority consumed by subjects is water $(4.2 \pm 1.22)$ at room temperature $(3.85 \pm 1.53)$. The average of drink frequency is 5.21 times per day and the average of daily fluid consumption is $1789 \mathrm{~mL}$.

The distribution of subjects by hydration status is presented in table 4. Among 93 subjects, majority were well hydrated, while $10.8 \%$ were slightly hydrated, $6.5 \%$ were moderately hydrated and $9.7 \%$ were severely dehydrated.

In Table 5, the result of Chi-square analysis of the association of subject's gender with hydration status was shown. Being male was more (PR 1.571) associated with being dehydrated compared to female, but this relationship was not found significant $(\mathrm{p}=0.282)$.

Table 6 showed that having moderate-vigorous level of physical activity were risk factor for being dehydrated although not statistically significant $(\mathrm{p}=0.433$ ) by using Chi-square analysis.

The fisher's exact test analysis in Table 7 pointed out that there is no significant relationship of body mass index with hydration status $(\mathrm{p}=0.355)$ though being obese was more associated with dehydration (PR 1.520) compared to non-obese.

Table 8 showed that there is negative strong correlation $(r=-0.651)$ of fluid consumption with urine specific gravity.

\section{Discussions}

In this study, $33.3 \%$ subjects are male and $66.7 \%$ are female. This finding is analogous to the data of 2014-2017 year medical student in Universitas Sriwijaya that male to female ratio is 1 to 2.4 . This study revealed that most subjects $(64.5 \%)$ was $\geq 19$ years old. The data from Universitas Sriwijaya also shows that dominantly student age is $>19$ years old. The age cutoff in this study is 19 years old, according to age cutoff of Indonesian recommended water intake.

From the International Physical Activity Questionnaire, this research shows that the majority of the subjects has low level of physical activity $(52.7 \%)$ and the least (6.5\%) has vigorous level of physical activity. The transportation of subjects in this study predominantly is motor vehicle $(66.66 \%)$ and the least $(3.23 \%)$ is bicycle. This research is not similar to the research by Bednarek et al. ${ }^{10}$ that stated more than half $(52 \%)$ of university students had moderate level of physical activity and only $11 \%$ had low level of physical activity.

Of all subjects in this study, $82.8 \%$ was nonobese. Research by Abdalla and Mohamed ${ }^{11}$ and research by Rao et al. ${ }^{12}$ also stated similar findings where the majority of medical students is nonobese. The majority $(53.8 \%)$ of fluid consumption in this study is adequate. This result found out to be suchlike with the findings by Zhang ${ }^{13}$ with subjects from medical students in China.

The fluid consumption counted in this study is provided by fluids (drinking water and beverages of all kind). According to EFSA Panel ${ }^{13}$, fluid consumption is mainly provided by fluid or $80 \%$ from daily water recommendation. Indonesian recommended water intake is referring to Indonesian Dietary Recommendation $2019^{14}$ that set $2.3 \mathrm{~L} /$ day for male age 16-18 years old, $2.5 \mathrm{~L} /$ day for male age 19-29 years old, $2.15 \mathrm{~L} /$ day for female age 16-18 years old, 2.35L/day for female age 19-29 years old.

The average fluid types majority consumed by subjects is water 4 times/day. According to the research conducted by Bardosono ${ }^{15}$, similar results were found. In that study, majority $(75 \%)$ of the subjects consumed water and only $1 \%$ drink other beverages. Malik et al. ${ }^{16}$ stated that intake soft drink and sugar-sweetened beverages is associated with weight gain. The average of daily fluid consumption is $1789 \mathrm{~mL}$. This finding is higher than research conducted by Zhang ${ }^{5}$ that showed average of daily 
fluid consumption is $1342 \mathrm{~mL}$ among medical students in China.

Majority $(73.1 \%)$ of the subjects were well hydrated. The research by Zhang $^{5}$ stated respectively $75 \%$ subjects was in optimal hydration state, which was similar to this research's finding. In this study, subjects that were in dehydration state can be caused by some factors including physical activity and ambient temperature. Furthermore, the hydration status is determined by urine specific gravity (USG) using urinometer. Whilst Proctor ${ }^{17}$ stated that urinometer is the gold standard for the measurement of urine specific gravity, the research of Stuempfle dan Drury ${ }^{18}$ found that urinometer has $88 \%$ sensitivity and $67 \%$ specificity. Subjects that were severely dehydrated may be caused by the urine collected in this study is first morning urine sample. First morning urine sample means that subject collected urine right after woke up, before drank and ate breakfast. When the subjects met researcher to collect the urine sample, subjects is assumed to have eaten and have drunk so that subjects did not have signs and symptoms of dehydration.

Chi square's analysis of the association between hydration status with gender. Prevalence ratio 1.571 means that being male was more (PR 1.571) associated with being dehydrated compared to female, but this relationship was not found significant $(p=0.282)$. In line with the study of Sari ${ }^{19}$ showing that there was no significant relationship ( $>0.05$ ) between hydration status with gender. According to Institute of Medicine (U.S) Panel $(2005)^{20}$ female has less turnover rate than male with the result that male is expected to be more dehydrated than female. But this result also can be different because of subject's fluid consumption. We propose future research to applicate multivariate analysis in consider to some other factors, including fluid consumption.

The hydration status showed no significant relationship with physical activity. Subjects with vigorous level of physical activity would be 1.417 times higher to become dehydrated than subjects with low-moderate level of physical activity. In contrast to this study, Aryani ${ }^{21}$ research showed that theres no significant relationship $(p>0.05)$ between hydration status with physical activity. Study of Rao et al. ${ }^{12}$ in medical students showed that $45 \%$ subjects claimed to have low physical activity because lack of time $(60.5 \%)$, laziness $(61.8 \%)$, and exhaustion from academic activity (42\%). In that research, the data of physical activity taken by questionnaire so that the results were very subjective. Nonetheless this research showed that moderate-vigorous activity is the risk of dehydration.

The result of fisher exact's test showed that there is no significant relationship $(p=0.355)$ between hydration status with body mass index. Andayani et al. ${ }^{22}$ research with subjects from industrial workers that there was no significant relationship $(p=0,072)$ between hydration status with nutrition status. Dehydration state is not only found in obese subjects but also nonobese subjects. Theoretically, the percentages of water in adipocytes is less than the percentages of water in myocytes. By that reason, obese people has less total body water than nonobese people. Hence, obese people were more associated with dehydration than nonobese people. The theory is contrast with the result of this study. This can happen because the nutrition status in this study was assessed by body mass index, not by body fat mass. Still this study showed that obese people has risk to become dehydration 1.520 times than nonobese people.

There was negative strong correlation $(\mathrm{r}=-0.651)$ of fluid consumption with urine specific gravity. Fluid consumption was assessed by selfadministered 7-day-24-hours fluid record and urine specific gravity was assessed by urinometer. This outcome was confirming the outcome of Zhang 5 research. The research of Zhang also showed strong relationship between urine biomerkers and fluid consumption. The different is Zhang used urine volume $(r=0.76)$ and urine osmolality $(r=0.76)$ as urine biomarkers. Subjects in optimal hydration state drank more fluid than subjects in another hydration state 5 .

There were several limitations in this study: limited instruments, fluid consumption from food was not taken and fluid records was not explained by trained nutritionist. However, this had been anticipated by researchers by using household utensil and photographs to help the subjects to remember and estimate the number and type of beverages. Additionally, in this study we did not count the fluid consumption from food since the 
food consumption can influence the total fluid consumption.

\section{Conclusion}

In summary, the majority subjects in this study were $\geq 19$ years old, had low level physical activity, nonobese and had adequate fluid consumption. The fluid types majority consumed by subjects is water at room temperature. The average of drink frequency

Table 1. General characteristics of subjects $(\mathrm{N}=93)$ is 5.21 times per day and the average of daily fluid consumption is $1789 \mathrm{~mL}$. Most subjects were in well hydrated state. Fluid consumption from beverages showed strong correlation with urine specific gravity. The hydration status showed no assciation with gender, physical activity and body mass index.

\begin{tabular}{llc}
\hline \multicolumn{1}{c}{ Characteristics } & $\mathrm{n}$ & $\%$ \\
\hline Gender & & \\
$\quad$ Male & 31 & 33.3 \\
Female & 62 & 66.7 \\
Age & & \\
$\quad<19$ years old & 33 & 35.5 \\
$\quad>19$ years old & 60 & 64.5 \\
\hline
\end{tabular}

Table 2. Specific characteristics of subjects

\begin{tabular}{|c|c|c|}
\hline Characteristics & $\mathrm{n}$ & $\%$ \\
\hline \multicolumn{3}{|l|}{ Physical activity } \\
\hline Vigorous & 6 & 6.5 \\
\hline Moderate & 38 & 40.9 \\
\hline Low & 49 & 52.7 \\
\hline \multicolumn{3}{|l|}{ Body mass index } \\
\hline Obese & 16 & 17.2 \\
\hline Non-obese & 77 & 82.8 \\
\hline \multicolumn{3}{|l|}{ Fluid consumption } \\
\hline Not adequate & 43 & 46.2 \\
\hline Adequate & 50 & 53.8 \\
\hline
\end{tabular}

Table 3. Fluid consumption pattern of subjects

\begin{tabular}{|c|c|}
\hline Fluid consumption pattern & Mean \pm SD \\
\hline \multicolumn{2}{|l|}{ Type of fluid (times/day) } \\
\hline Water & $4.2 \pm 1.22$ \\
\hline Hot coffee and tea & $1.05(1.03-1.1)^{*}$ \\
\hline Milk and derivatives & $1 \quad(0-2)^{*}$ \\
\hline Soft drinks & $(0-2.6)^{*}$ \\
\hline Other beverages & $(0-1)^{*}$ \\
\hline \multicolumn{2}{|l|}{ Temperatures (times/day) } \\
\hline Chilled with ice cubes & $(0-3)^{*}$ \\
\hline Chilled without ice cubes & $(0-4.8) *$ \\
\hline Warm & $(0-3) *$ \\
\hline Room temperature & $3.85 \pm 1.53$ \\
\hline Frequency(times/day) & $5.21 \pm 1.16$ \\
\hline Daily fluid consumption (mL) & 1789.3(989-2930)* \\
\hline
\end{tabular}

* Median (Min-Max) 
Table 4. Distribution of subjects by hydration status

\begin{tabular}{ccc}
\hline Hydration status & $\mathrm{n}$ & $\%$ \\
\hline Well hydrated & 68 & 73.1 \\
Slightly dehydrated & 10 & 10.8 \\
Moderately dehydrated & 6 & 6.5 \\
Severely dehydrated & 9 & 9.7 \\
\hline
\end{tabular}

Table 5. The relationship of gender with hydration status $(\mathrm{N}=93)$

\begin{tabular}{|c|c|c|c|c|c|c|c|}
\hline & \multicolumn{4}{|c|}{ Hydration status } & \multirow[t]{3}{*}{ Total } & \multirow[t]{3}{*}{ PR } & \multirow[t]{3}{*}{$p$} \\
\hline & \multicolumn{2}{|c|}{ Dehydrated } & \multicolumn{2}{|c|}{ Not dehydrated } & & & \\
\hline & $\mathrm{n}$ & $\%$ & $\mathrm{n}$ & $\%$ & & & \\
\hline \multicolumn{8}{|l|}{ Gender } \\
\hline Male & 11 & 35.5 & 20 & 64.5 & 31 & \multirow{2}{*}{1.571} & \multirow{2}{*}{0.282} \\
\hline Female & 14 & 16.7 & 48 & 77.4 & 62 & & \\
\hline
\end{tabular}

Table 6. The relationship of physical activity level with hydration status (N=93)

\begin{tabular}{|c|c|c|c|c|c|c|c|}
\hline & \multicolumn{4}{|c|}{ Hydration status } & \multirow[t]{3}{*}{ Total } & \multirow[t]{3}{*}{ PR } & \multirow[t]{3}{*}{$p$} \\
\hline & \multicolumn{2}{|c|}{ Dehydrated } & \multicolumn{2}{|c|}{ Not dehydrated } & & & \\
\hline & $\mathrm{n}$ & $\%$ & $\mathrm{n}$ & $\%$ & & & \\
\hline \multicolumn{8}{|l|}{ Physical activity } \\
\hline Moderate-vigorous & 14 & 31.8 & 30 & 68.2 & 44 & \multirow{2}{*}{1.417} & \multirow{2}{*}{0.433} \\
\hline Low & 11 & 22.4 & 38 & 77.6 & 49 & & \\
\hline
\end{tabular}

Table 7. The relationship of body mass index with hydration status ( $=93$ )

\begin{tabular}{|c|c|c|c|c|c|c|c|}
\hline & \multicolumn{4}{|c|}{ Hydration status } & \multirow[t]{3}{*}{ Total } & \multirow[t]{3}{*}{ PR } & \multirow[t]{3}{*}{$p$} \\
\hline & \multicolumn{2}{|c|}{ Dehydrated } & \multicolumn{2}{|c|}{ Not dehydrated } & & & \\
\hline & $\mathrm{n}$ & $\%$ & $\mathrm{n}$ & $\%$ & & & \\
\hline \multicolumn{8}{|c|}{ Body mass index } \\
\hline Obese & 6 & 37.5 & 10 & 62.5 & 16 & \multirow{2}{*}{1.520} & \multirow[t]{2}{*}{0.355} \\
\hline Non obese & 19 & 24.7 & 58 & 75.3 & 77 & & \\
\hline
\end{tabular}

Table 8. The relationship of fluid consumption with hydration status $(\mathrm{N}=93)$

\begin{tabular}{c|cc}
\hline & \multicolumn{2}{c}{ Urine specific gravity } \\
\cline { 3 - 3 } & \multicolumn{2}{c}{$\mathrm{p}$} \\
\hline Fluid consumption & -0.651 & 0.000 \\
\hline
\end{tabular}




\section{Acknowledgments}

The authors would like to acknowledge all the subjects for their participation and the Nutrition Department, Faculty of Medicine, Universitas Sriwijaya, for the study conduct.

\section{Conflict of Interest}

No potential conflicts of interest to declare in relation to this publication.

\section{Open Access}

This article is distributed under the terms of the Creative Commons Attribution 4.0 International Licence (http://creativecommons.org/licenses/by/4.0/), which permits unrestricted use, distribution, and reproduction in any medium, provided you give appropriate credit to the original author(s) and the source, provide a link to the Creative Commons license, and indicate if changes were made.

\section{References}

1. Armstrong L.E. Assessing hydration status: the elusive gold standard. Am Coll Nutr J 2007; 26(5): 575s-584s.

2. Ross, A.C. Modern Nutrition In Health and Disease, Eleventh Edition. Philadelphia: Wolters Kluwer Health/Lippincott Williams \& Wilkins, 2012.

3. Mahan L.K., Raymond J.L. Krause's Food \& The Nutrition Care Process. St.Louis: Elsevier, 2016.

4. Thompson J.L., Manore M.M. dan Vaughan L.A. The Science Of Nutrition: The Second Edition. United States: Benjamin Cummings Publishing Company, 2011.

5. Zhang N., Du S., Tang Z. et al. Hydration, fluid intake, and related urine biomarkers among male college students in Cangzhou, China: a crosssectional study--applications for assessing fluid intake and adequate water intake. Int J Environ Res Public Health 2017; 14(5): 513-524.

6. Jalali E. Water consumption and factors influencing hydration status. Master's Thesis. Loughborough University, 2012.

7. Dieny F. dan Putriana D. Status hidrasi sebelum dan sesudah latihan atlet sepak bola remaja. Jurnal Gizi Indonesia 2015; 3(2): 86-93.

8. Buanasita. Perbedaan tingkat konsumsi energi, lemak, cairan, dan status hidrasi mahasiswa obesitas dan nonobesitas. Ind J Hum Nutr 2015; 2(1): 11-22

9. Merhej, R. Dehydration and cognition: an understated relation. Int J. Health Gov. 2019; 24(1): 19-30.

10. Bednarek J., Pomykala S., Bigosinska M. et al. Physical activity of Polish and Turkish university students as sssesses by IPAQ. Centr Eur J of Sport Sci Med. 2016.18 (4): 13-22

11. Abdalla S. dan Mohamed E. Obesity among medical students of the national Ribat University. Sudanese $J$ Pub Health. 2012; 4:90-97

12. Rao C., Darshan BB., Das N. et al. Practice of Physical Activity among Future Doctors: A Cross Sectional Analysis. Int J Prev Med 2012; 3(5):365- 369.

13. EFSA Panel on Dietetic Products, Nutrition, and Allergies (NDA). Scientific opinion on dietary reference values for water. EFSA Journal. 2010; 8(3): 1459 .

14. AKG. Angka Kecukupan Gizi Yang Dianjurkan Untuk Masyarakat Indonesia. Peraturan Kementrian Kesehatan Republik Indonesia Nomor 28 Tahun 2019.

15. Bardosono S., Guelinckx I. dan Monrozier R. Total fluid intake assessed with a 7-day fluid record versus a 24-h dietary recall: a crossover study in Indonesian adolescents and adults. Eur J Nutr 2015; 54(2): 17-25

16. Malik V.S., Schulze M.B., dan Hu F.B. Intake of sugarsweetened beverages and weight gain: a systematic review. Am J Clin Nutr 2006; 84(2):274-288.

17. Proctor D.B. dan Adams A.P. Kinss's The Medical Assistant - E-Book: An Applied Learning Approach. California: Elsevier Helath Science, 2014.

18. Stuempfle K.K. dan Drury D.G.Comparison of 3 methods to assess urine specific gravity in collegiate wrestlers. J Athl Train. 2003; 38(4): 315-319

19. Sari, Okky. Perbedaan Peningkatan Konsumsi Air Minum, Status Hidrasi, dan Kebugaran Jasmani Berdasarkan Jenis Kelamin pada Remaja Setelah Pemberian Edukasi yang Disertai Air Minum. Tesis Master. Universitas Gadjah Mada, Indonesia, 2016.

20. Institute of Medicine (U.S.) Panel. Dietary reference intakes for water, potassium, sodium, chloride, and sulfate. Washington DC: The National Academies Press; 2005

21. Aryani, P. Hubungan antara aktivitas fisik, pola makan dan kebiasaan merokok terhadap kejadian dislipidemia pada pegawai negeri sipil. Universitas Gadjah Mada yang medical check-up di GMC- Health Center Yogyakarta. Tesis Master. Universitas Gadjah Mada, Indonesia, 2014.

22. Andayani, K. Hubungan Konsumsi Cairan dengan Status Hidrasi pada Pekerja Industri Laki-Laki. Skripsi Gizi. Universitas Dipenogoro, Indonesia, 2013. 